\title{
The Collared Snake (Coluber natrix) in the Sea.
}

By Dr. J. E. Gray, F.R.S.

It has been stated by several persons that Sea-Snakes are sometimes found in the European seas, and even on English coasts, as far north as the Orkneys, their appearance in the latter locality being accounted for by their having been carried there by the Gulf-stream, which might perhaps happen with some American species; but the specimens shown to me have all been the common Collared Snake (Coluber natrix), and I have been inclined to doubt the accuracy of the statements, as they were not well authenticated, and on examination were generally found to have come through two or more persons before they reached me. The other day the Secretary of the Montrose Natural History Society showed me a specimen of Coluber natrix which was taken up in a bucket in the sea, about twenty-five miles from the Naze on the coast of Norway. It lived some time aboard, and arrived alive at Montrose and was there put in spirits.

This Snake is aquatic in its habits, often found in ponds and ditches, where it goes to catch frogs, fish, \&c. It has no near relation to what are usually called Sea-Snakes (Hydridce). This Coluber may have been washed down by the floods into the sea, as the Boas are said by Guilding to be in the West Indies.

\section{On the Jaw of Cylindrella. By T. Buand.}

42 Pine Street, New York, 12th October, 1868.

My Dear SrR, - I have lately made an unlooked-for discovery, which I announce to you, to whom all are so much indebted for labours with reference to classification.

I find that Cylindrella, as well as Macroceramus, has a jaw, in both of much the same character. Lately I received several species either alive or in glycerine; and immersion in a solution of caustic potash enabled me with comparative ease to detect the jaw. Being very minute and delicate, I do not wonder at this having escaped notice. I had previously examined dead and dried-up specimens only of the Cylindrella-Mangei group.

I have both jaws and lingual bands of
Cylindrella sanguinea, $\mathrm{Pf}$.
C. gracilis, Wood. Jamaica. Jamaica.
C. Maugei, Wood. Jamaica.
C. rosea, Pf. Jamaica.
C. brevis, Pf. Jamaica.
C. elongata, Ch. Jamaica.
C. trinitaria, n. sp. Trinidad.
C. bahamensis, n. sp. New Providence.

I shall publish this with figures; meantime I take pleasure in informing you, as I have Dr. Pfeiffer, through Mr. Crosse.
Dr. John E. Gray, British Museum. I am, my dear Sir, Very truly yours, T. BLAND.

Remarks on the Development of Marine Fishes. By G. O. SARs.

It has long been supposed that the codfish deposit their ova at the bottom of the sea. M. G. O. Sars has recently shown that this 


\section{$2 \mathrm{BHL}$ Biodiversity Heritage Library}

Bland, Thomas. 1868. "On the jaw of Cylindrella." The Annals and magazine of natural history; zoology, botany, and geology 2, 389-389.

https://doi.org/10.1080/00222936808695831.

View This Item Online: https://www.biodiversitylibrary.org/item/72302

DOI: https://doi.org/10.1080/00222936808695831

Permalink: https://www.biodiversitylibrary.org/partpdf/61354

\section{Holding Institution}

University of Toronto - Gerstein Science Information Centre

\section{Sponsored by}

University of Toronto

\section{Copyright \& Reuse}

Copyright Status: NOT_IN_COPYRIGHT

This document was created from content at the Biodiversity Heritage Library, the world's largest open access digital library for biodiversity literature and archives. Visit BHL at https://www.biodiversitylibrary.org. 